The Clan Fingon

Author(s): A. Maclean Sinclair

Source: The Celtic Review, Vol. 4, No. 13 (Jul., 1907), pp. 31-41

Published by:

Stable URL: http://www.jstor.org/stable/30069919

Accessed: 23-12-2015 23:37 UTC

Your use of the JSTOR archive indicates your acceptance of the Terms \& Conditions of Use, available at http://www.jstor.org/page/ info/about/policies/terms.jsp

JSTOR is a not-for-profit service that helps scholars, researchers, and students discover, use, and build upon a wide range of content in a trusted digital archive. We use information technology and tools to increase productivity and facilitate new forms of scholarship. For more information about JSTOR, please contact support@jstor.org. 


\section{THE CLAN FINGON}

\section{Rev. A. Maclean Sinclair}

I. THE personal name Fingon, in Gaelic Fionn-ghin, Fionghuin or Finghin, means fair offspring or fair bairn. It appears among the Irish, Scots and Picts. In the tale known as Tain Bo Chuailgne we meet with it as the name of a wonderful physician who could cure a man after a large, rough ball had crushed through his skill and lodged firmly in his brain. Fingon was the name of the King of Munster in 896 A.D. It was also the name of the Bishop of Iona in 965. As mac is pronounced in the southern parts of the Highlands as if written machk, and as $\mathrm{fh}$ is silent, the surname MacFhionghinn is pronounced as if written Machkionghinn, and becomes in English Mackinnon.

According to the oldest and most valuable genealogies of the Highland clans the Mackinnons are descended from Fingon, son of Cormac, son of Airbeartach, son of Fearchar $\mathrm{Og}$, son of Fearchar Fada. This pedigree may be regarded as genuine from Fingon to Airbeartach, but not any further.

II. Finlay, son of Fingon, had a son named Ewen.

Finlay, in Gaelic Fionnla, is from fionn laoch, and means fair hero-a very fine name, although not very popular among those who rejoice in pretty names, whether they mean pretty things or ugly things. Surely, the first thing to be considered in giving a name to a child is what the name really means.

III. Ewen, son of Finlay, is known in the genealogy of the Mackinnons as Seann Eoghann, or Old Ewen.

IV. Gillebride or Gilbride, son of Ewen, may have fought at the battle of Bannockburn in 1314.

V. Ewen, son of Gilbride, was known as Ewen Og, or Young Ewen.

Dugald, son of Somerled and progenitor of the Macdougalls of Lorn, succeeded his father in Lorn, Morvern, 
Ardnamurchan, Lismore, Kerrera, Seil, Luing, Shuna, Scarbra, Jura, Iona, Ulva, Mull, and Tiree. Alexander, son of Ewen, son of Duncan, son of Dugald, joined the Cummings against Robert Bruce and was deprived of his estates in 1314. In 1343 David Bruce granted to John, first Lord of the Isles, a charter of Morvern, Lochaber, Duror, Glencoe, Islay, Gigha, Jura, Scarba, Colonsay, Mull, Iona, Ulva, Tiree, Coll and Lewis, together with the castles of Kernaburgh, Iselburgh, and Dunconnel. Some time afterwards he gave to John Macdougall, son of Alexander, a charter of the district of Lorn and the islands adjoining it. There was a disagreement about lands for a long time between John of Islay and John of Lorn. Although the former had a legal claim to the lands of Duror, Mull, and Jura, the latter held possession of these lands and refused to part with them. In 1354 the matters in dispute were amicably settled, and on the following terms: John of Lorn, Lord of Argyll, surrendered to John of Islay, Lord of the Isles, the lands of Duror, Mull, and Jura, and the castles of Kernaburgh, Iselburgh and Dunconnell. John of Islay gave up all claim to the island of Coll, and granted and confirmed it to John of Lorn. John of Islay also bound himself never to give the keeping of the castle of Kernaburgh to any of the race of the clan Fingon. It is evident that for some reason or other John of Lorn disliked the Mackinnons. Probably they had not been as faithful to him in his disputes with the Lord of the Isles as he thought they should have been.

VI. Gilbride, son of Eoghann Og, had two sons, Neil and Fingon. It is possible that his wife was a daughter of Neil Maclean, brother of John Dubh.

The Macleans and the Mackinnons were originally followers of the Lords of Lorn, and held lands under them. After John of Lorn had surrendered Mull to the Lord of the Isles, Lachlan Lùbanach and Hector Reaganach, sons of John Dubh Maclean, went to Ardtornish to see the Lord of the Isles in connection with their lands. They did not receive as favourable a reply to their requests as they could desire. 
It is said that Mackinnon, probably Gilbride, was jealous of their rising influence, and treated them in a very insulting manner. The story of his unkind treatment of them may be dismissed as a fiction. The probability is that he treated them civilly enough, but that he was using his influence with the Lord of the Isles to prevent him from granting their requests. He may have wanted some of the lands claimed by them for himself. Lachlan Lùbanach and Hector Reagunach were both daring men and were capable of desperate deeds. They slew Mackinnon, took possession of his boat, and manned it with their own followers. They went then in pursuit of the Lord of the Isles, who had left Ardtornish for Mull. They captured him, and took him with them to Iona, where they compelled him to grant them the lands they wanted, and also to pardon them for the slaughter of Mackinnon, and for the liberties they had taken with himself. Lachlan received the lands of Duart and Hector the lands of Lochbuie. In 1366 Lachlan married Margaret, daughter of the Lord of the Isles, and had by her Hector Roy, his successor.

VII. Neil, son of Gilbride, was born probably about 1360 , and was chief of the Mackinnons in 1385. He married, apparently, Maria, daughter of Lachlan Lùbanach of Duart, and had Lachlan and another son.

Fingon, Neil's brother, was Abbot of Iona, and was known as the Green Abbot. He was an able, crafty, and eloquent man. He instigated John Mor Tanaistear to quarrel with his brother Donald and rise in rebellion against him. The rebellion was crushed in the bud and without any fighting. John Mor repented of his rashness and became reconciled to his brother. According to the Sleat historian, Neil was put to death by Donald of the Isles for having joined his brother the Green Abbot in the rebellion which the latter had stirred up against Donald. There is evidently no truth in this story. Neil was probably dead before the year 1409, whilst John Mor's rebellion, if there ever was such a thing, could not have taken place voL. IV. 
until after 1411. The Green Abbot left two sons and a daughter.

VIII. Lachlan, son of Neil, succeeded his father as chief of the Clan Fingon, and was known as Lachainn Fògarach, or Lachlan the Exile. He witnessed a charter granted in 1409 by Donald, Lord of the Isles, to Hector Roy of Duart. His appearing as a witness to this charter favours the supposition that his mother was a sister of Hector Roy.

The two sons of the Green Abbot murdered Lachlan's brother and intended to murder himself. He left his house and lived for a short time in caves and other hiding-places. By the help of the Fergusons, who had fostered his brother, he was enabled to seize the Abbot's two sons and put them to death.

IX. Lachlan, successor of Lachlan, was known as Lachainn na h-Iomlaid, or Lachlan the Barterer.

The original possessions of the Mackinnons in the Isle of Mull consisted apparently of the district of Gribun and some lands which had belonged to the Church. Lachlan exchanged the lands of Gribun for the lands of Mishnish, of which he received a charter from the Lord of the Isles. It was in consequence of this exchange that he came to be known as Lachlan of the Barter. He witnessed a charter granted by John, fourth Lord of the Isles, in 1467, and is described as Lachlan MacFingon of Mishnish. $\mathrm{He}$ seems to have been the first Mackinnon chief who held a charter of the lands occupied by himself and his followers. He had three sonsNeil, John, and Ewen. John was Abbot of Iona, and in 1489 erected a handsome cross in memory of his father and himself. He died in 1500. Ewen had two sons, Neil and Donald.

X. Neil Bàn, son of Lachlan, succeeded his father in the chiefship of the Clan Fingon.

After the forfeiture of the Lordship of the Isles in 1493 it became necessary for the smaller clans, as a matter of selfprotection, to join the more powerful clans. The Macneils of Barra, the Mackinnons, and the Macquarries joined the 
Macleans of Duart and supported them in their wars. The Macneils of Gigha joined the Macdonalds of Islay.

In 1515 Lachlan Cattanach of Duart supported Sir Donald Macdonald of Lochalsh in his rebellion. In 1517 we find a free remission granted to Lachlan Cattanach for himself and his associates, namely, Donald Maclean his uncle, Gilleonan Macneil of Barra, Neil Mackinnon of Mishnish, Dunslaff Macquarrie of Ulva, and Lachlan Maclean of Ardgour. At the same time the king granted to Lachlan Cattanach the four marklands of Scalpa. In 1609 we find Hector $\mathrm{Og}$ of Duart in possession of a part of Scalpa.

The Mackinnons received the lands of Strathordill in Skye from the Lord of the Isles sometime after 1437. They received a part of the island of Scalpa from Maclean of Duart in exchange for some lands in Mull.

XI. Ewen, son of Neil, was chief of the Clan Fingon in 1531, and is described as Ewen Mac Fingon of Strathordill. He was popularly known as Eoghann Ruadh nan Cath, or Ewen Roy of the Battles. In 1539 he assisted Donald Gorm of Sleat in his attack on Ellandonan Castle. In August 1542 , among those who received a remission for that attack we find Ewen of Strathordill, Neil Mac Ewen Mac Lachlan, and Donald Mac Ewen Mac Lachlan. In August 1542 Ewen received a Crown charter of the twenty marklands of Mishnish in Mull and the twenty marklands of Strathordill in Skye. He was among the supporters of Donald Dubh Macdonald in 1545. He received a remission in 1546 for all past offences. He was evidently a man of action.

XII. Lachlan, son of Ewen Mac Fingon, was served heir to his father in July 1557 in the lands of Mishnish and Strathordill. This chief was known as Lachainn Dubh, or Black Lachlan. In 1562 the Macdonalds of Islay and the Macdonalds of Sleat invaded the islands of Mull, Coll, and Tiree, carried off all the valuable things they could find, set fire to the buildings, and slew a number of persons. This was the beginning of the deplorable war between the Macleans of Duart and the Macdonalds of Islay. Among those who 
assisted the Macdonalds of Sleat in plundering the Maclean lands were Donald Mackinnon, John, son of Hector Mackinnon, and John Dubh Mackinnon. These Mackinnons may or may not have lived in Strathordill, but the probability is that they did not. The Mackinnons as a clan had nothing to do with the invasion of the Maclean territories.

Lachlan Dubh had four sons-Lachlan Og, Terlach Sgitheanach, Ewen, and John. He died about 1580. Terlach Sgitheanach had one son, Lachlan Roy, who appears on record in 1634 as Lachlan $\mathrm{M}^{\mathrm{c}}$ Charles V. ${ }^{\mathrm{c}}$ Fingon.

XIII. Lachlan Og Mac Fingon was born about 1540, and was served heir to his father, in July 1581, in the lands of Mishnish and Strathordill.

In July 1586 Sir Lachlan Mor Maclean of Duart was seized at Mullintrea by Angus Macdonald of Islay and thrown into prison. The guardians of the young Earl of Argyll, acting under instructions from King James VI., procured the release of Sir Lachlan Mor by promising Angus of Islay a free pardon and placing the following hostages in his hands: Hector, son and heir of Sir Lachlan Mor; Alexander, brother of William Macleod of Dunvegan; Lachlan and Neil, sons of Lachlan Og of Strathordill ; John and Murdoch, sons of Macneil of Barra; Allan, son of Ewen Maclean of Ardgour ; and Donald, son of Hector Maclean of Treshnish. In the autumn of 1588 the warlike lord of Duart had John Macdonald of Ardnamurchan and other prominent Macdonalds in his hands as prisoners, and felt at liberty to renew the war. If the Macdonalds should murder their hostages, the Macleans could retaliate by murdering their prisoners. Lachlan Mor, accompanied by his supporters, immediately invaded the islands of Canna, Rum, Eigg, and Muck. He plundered the tenants, gave their houses to the flames, and put several persons to death. If the Macdonalds acted with ferocity in 1562, the Macleans acted with equal ferocity in 1588. The hostages were set at liberty in March 1589. At the same time Lachlan Mor of Duart, Macneil of Barra, Lachlan Og of Strathordill, Macquarrie of Ulva, and Ewen of Ardgour 
received a full remission for their doings in Canna, Rum, Eigg, and Muck.

Lachlan Og had two sons, Lachlan and John Og. John Og was living in July 1618, but died shortly afterwards. Neil, son of John Og, was born about 1600, graduated at the University of Glasgow in 1626, and became minister of Strath in 1627. He was translated to Sleat in 1641, and died sometime after 1661 .

XIV. Lachlan, son of Lachlan Og, succeeded his father. In January 1601 he entered into a bond of friendship with Archibald, seventh Earl of Argyll. In 1606 he obtained a bond of manrent from Finlay Macnab of Bowaine. In 1613, or shortly afterwards, he received the honour of knighthood from James VI. In 1615 he took an active part in suppressing the rebellion of Sir James Macdonald of Islay. In July 1616 Sir Lachlan and a number of other Highland chiefs appeared before the Privy Council and bound themselves to keep their followers in subjection to the laws of the land. Sir Lachlan named the following persons as rebellious men for whose actions he would not be responsible: Donald Riabhach son of Terlach, John son of Terlach son of Donald, Angus son of Donald son of Neil, Donald son of Neil Gorm, and John Roy son of Terlach. In August 1616 Sir Rory Mor Macleod of Dunvegan, Donald, captain of the Clanranald, Sir Lachlan of Strathordill, and Lachlan Maclean of Coll met in the city of Glasgow and entered into a bond of mutual friendship. In January 1628 Charles I. created the lands of Strathordill into a barony. Sir Lachlan died shortly afterwards, and left three children, Iain Balbhan or John 'the Dummy,' Mary and Jane. Mary was married, as his second wife, to Sir Roderick Macleod of Talisker.

XV. John Balvan married in 1627 Catherine, daughter of Lachlan Maclean of Coll, and had by her one son, Lachlan Mor. He was killed in 1641 by an arrow whilst standing on the summit of his castle at Dunara. The arrow came from Tom-na h-Aithne, and was evidently aimed at John with the 
intention of terminating his life. The murderer, whoever he may have been, escaped punishment from man.

XVI. Lachlan Mor, son of John Balvan, was born in 1628. He was taken to Inveraray immediately after the death of his father and placed under the protection of the Earl of Argyll. On February 14, 1642, John Garbh Maclean of Coll, his maternal uncle, was appointed tutor-dative to him. He returned to Skye in 1651. He fought on behalf of Charles II. at the battle of Worcester in 1651. He entered into a bond of friendship with James Macgregor, chief of the Clan Gregor, in 1671. He married, first, Mary, daughter of Sir Lachlan Maclean of Duart, and, secondly, Marion Macleod. He died about 1700.

It is asserted by some writers that Lachlan Mor was knighted by Charles Ir. on the battlefield of Worcester. For this assertion it is impossible to produce a particle of evidence. Lachlan Mor is mentioned in several authentic documents, but he is never styled Sir Lachlan. In a Gaelic poem written in praise of him he is referred to simply as Lachlan. The probability then is that, whilst he was a gallant soldier, he never received the honour of knighthood from King Charles.

Lachlan Mor left at least two lawful sons, John Og by his first wife, and John of Mishnish by his second wife. He left also a natural son named Donald, who is mentioned in an authentic document of the year 1688. It is maintained by some members of the Clan Fingon that he left two sons by his first wife, John Og and Donald, whilst others strenuously maintain that he had no son named Donald either by his first or second wife.

XVII. John, son of Lachlan Mor by his first wife, married Isabell, daughter of Donald Macdonald of Castleton, by his wife Margaret, daughter of John Cameron of Lochiel, and had by her John Dubh. John died on the night on which his son was born.

XVIII. John Dubh was born in 1682, and succeeded his grandfather in the chiefship about 1700 . He fought in behalf of the Stuarts at the battle of Sheriffmuir in 1715. 
He was attainted for his loyalty and deprived of his lands. $\mathrm{He}$ fought again in behalf of the Stuarts at the battle of Culloden in 1746. He assisted Prince Charles when that unfortunate young man was wandering about in the Western Islands. For his kindness to the Prince he was arrested on July 10, 1746, taken to London and kept in confinement until July 1747. He married, first, Penelope, daughter of Archbishop Sharpe, and had by her John Og his heir. He married, secondly, in 1743, Janet, daughter of Malcolm Macleod of Raasay, and by her had Charles, Lachlan, and Margaret. John Og, his eldest son, was married, and had four daughters, Florence, Helen, Margaret, and Penelope. Florence was married in 1759 to Ranald, 18th of Moidart. John died in 1737. Lachlan, third son of John Dubh, died unmarried in Jamaica, John Dubh died at Kilmorie, Isle of Skye, in his old home, May 7, 1756.

XIX. Charles, second son of John Dubh, was born in 1753, and succeeded his father as chief of the Mackinnons in 1756 .

The Laird of Grant purchased the Mackinnon estates from the British Government in 1723, and conveyed them in 1728 to Neil Mackinnon, son of Mackinnon of Corry. On receiving the estates Neil Mackinnon conveyed them to John, son and heir of John Dubh, and his heirs-male, whom failing to any other son or sons of John Dubh, and their heirsmale, whom failing to John Mackinnon of Mishnish, son of Lachlan Mor by his second wife, Marion Macleod. John, son of John Dubh, was now laird of Strathordill and Mishnish. Of course he had to pay the sum expended by the laird of Grant in purchasing the estates. In 1729 he borrowed some money from Sir Alexander Macdonald of Sleat. Between 1735 and $1745 \mathrm{Sir}$ Alexander bought up several of the debts on the Mackinnon lands. John Og ordered in his will that 30,000 marks should be paid out of his estates to his daughters. In $1738 \mathrm{John}$ of Mishnish, son of Lachlan Mor by his second wife, was served heir of provision in the lands of Strathordill and Mishnish. In 1751 John sold the whole 
of the estates except Strathaird and Mishnish to John Mackenzie, trustee for Sir James Macdonald of Sleat. After the death of John Dubh in 1756, Malcolm Macleod of Raasay succeeded through an expensive lawsuit with John of Mishnish in getting his grandson, Charles son of John Dubh, put in possession of the lands of Strathaird and Mishnish. These lands, however, were heavily burdened with debt. Charles Mackinnon sold the lands of Mishnish shortly after 1774 . He sold the lands of Strathaird to Alexander Macalister in 1789 for $£ 8400$. The Mackinnons were now a landless clan.

Charles Mackinnon married Alexandra, daughter of John, son and heir of Norman Macleod of Dunvegan, and had three children by her, John, Penelope, and Emilia. He died at Dalkeith in poor circumstances in 1796. Emilia was married to Alexander Mackinnon, banker at Naples.

XX. John, son of Charles, succeeded his father as chief of the Mackinnons. He died at Leith, unmarried, in 1808.

I have seen some traditions which refer to feuds and battles between the Macleans and the Mackinnons. These traditions are evidently modern fictions. The Macleans and the Mackinnons were subject to the Lords of Lorn from their first settlement in Mull to the year 1354, and to the Lords of the Isles from 1354 to 1493 . It is a sure thing that the Lords of Lorn and the Lords of the Isles would never have allowed them to quarrel and fight and slay one another. It is probable that there were rascals in both clans who were ready to quarrel with their neighbours and wrong them. It would be unreasonable, however, to exalt the squabbles of individuals into clan feuds.

It is said that there is a tradition to the effect that Lachlan Mor of Strathordill went to the assistance of his father-in-law, Sir Lachlan Maclean of Duart, with two hundred men, that Sir Lachlan and himself invaded the lands of the Campbells, and that the Campbells attacked them and routed them and slew a hundred of the Mackinnons. There is not one grain of truth in this tradition; it is an invention of the 
imagination from beginning to end, and a very late invention. I presume, however, that it arose from the fact that the fiery Sir Hector Roy of Duart, Lachlan Mor's wife's brother, and seven hundred and sixty of his followers were slain at the battle of Inverkeithing, July 2, 1651. Lachlan Mor was not at the battle of Inverkeithing, but he was at the battle of Worcester, September 3, 1651, and must have lost a number of his men there. It was against Cromwell, not against the Campbells, that the Macleans and the Mackinnons had been fighting. Possibly the Campbells could have thrashed them both, even on July 1, 1651, if they had invaded the Campbell lands; but they did not meddle with the Campbells, and the Campbells did not thrash them.

I have given the Mackinnon names in the line of descent. It is possible that two or three of the men in that line died at a comparatively early age, and that they were not actually chiefs; whilst it is probable that one or two of the chiefs died without male issue and are consequently unknown to history.

\title{
THE CORNISH DRAMA.-II
}

\author{
HENRY JENNER \\ (Continued from p. 375) \\ Analysis of the Dramas
}

I. Ordinale I. Origo Mundi (15th century)

Act I.

1. The Creation of the World. The six days described in seven stanzas spoken by the Father, who descends from the pulpitum, and creates Adam and places him in Paradise. Lucifer appears from heaven. The Creation of Eve and the naming of the animals. The scene closes with the institution of the Sabbath.

2. The Temptation and Fall of Man and the Expulsion from Paradise. The Father promises the Oil of Mercy. 